\title{
繰返し内圧及び温度変化を受ける管フランジ締結体の有限要素応力解析と 密封性能評価*
}

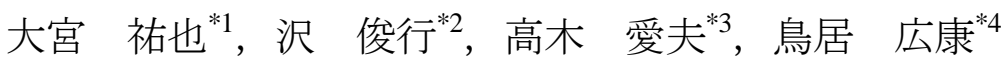

\section{FEM Stress Analysis and Sealing Performance Evaluation of Pipe Flange Connection under Cyclic Internal Pressure and Thermal Changes}

\author{
Yuya OMIYA*1, Toshiyuki SAWA, Yoshio TAKAGI and Hiroyasu TORII \\ ${ }^{* 1}$ Graduate School of Engineering, Hiroshima University \\ 1-4-1, Kagamiyama, Higashihiroshima city, Hiroshima, 739-8527, Japan
}

The effects of cyclic internal pressure and thermal changes on the sealing performance and mechanical behaviors in pipe flange connection are examined using the FEM analyses for pipe flange connections with spiral wound gasket (SWG). The contact gasket stress distributions and the axial bolt forces taking into account the cyclic internal pressure and thermal changes are demonstrated. The load (internal pressure, thermal changes) sequences are determined from the conditions for actual pipe flange connections used in petroleum and chemical plants. Furthermore, the effect of material differences between pipe flange and bolts on the contact gasket stress distribution are examined. From the FEM results, it is found that the contact gasket stress reduces to be the smallest when a plant is restarted. The reduced contact gasket stress should be taken into account in the sealing design of the connection. On the other hand, the leakage tests were carried out to verify the FEM results and the effect of number of cycles (for 21days). A fairy good agreement is seen between the estimated amount of leakage due to the contact gasket stress distributions obtained from the FEM and the measured amount of leakage. It is found that the contact gasket stress decreases when the plant is restarted and as the temperature decreases. At that time, the contact gasket stress is the smallest which may lead to a leakage accident.

Key Words : Mechanical Structure, Pressure Vessel, Bolted Connection, Pipe Flange, Gasket, Internal Pressure, Thermal Condition, Sealing Performce, FEM Stress Analysis

\section{1. 緒言}

石油精製, 石油化学プラントなどの各種機械構造物では, その配管接合部にガスケット付き管フランジ締結体 が多用されている．最近の使用条件の過酷化に伴い，ガスケット付き管フランジ締結体は内圧作用下及び高温度 作用下で使用されることも多い. ガスケット付き管フランジ締結体の内圧及び温度変動下における力学特性（ガ スケット接触応力分布及び八ブ応力等）及び漏えいに関わる密封性能については数多くの研究(1) (8)がなされてい る.これらの研究により管フランジ締結体に温度上昇が発生すると一般的にガスケット（ジョイントシート，う ず巻き形など）と管フランジとの線膨張係数の差異からガスケット接触応力が上昇し，管フランジ締結体の密封 性能が向上寸ることが知られている( ${ }^{(8)}$. しかし, これらの結果は, 各種プラントの運転の工程全体から考えると, 配管締結の施工から運転開始までの一時的又は短期的な条件下のみでの結果である. 実際の各種プラント内のガ スケット付き管フランジ締結体はより長期的に使用されるためガスケットの応力緩和やクリープ特性によりガス

\footnotetext{
* 原稿受付 2012 年 8 月 23 日

${ }^{* 1}$ 正員, 広島大学大学院 工学研究科 機械システム工学専攻 (テ739-8527 広島県東広島市鏡山 1-4-1)

${ }^{*} 2$ 正員, フェロー, 広島大学大学院 工学研究院 機械システム工学専攻

*3 正員, 東京電力 (株) 技術開発本部 技術開発研究所 材料技術センター 構造材料技術グループ （厂230-8510 神奈川県横浜市鶴見区江ヶ崎町 4-1）

*4 東京電力 (株)

E-mail: d102646@hiroshima-u.ac.jp
} 
ケット接触応力の低下や，また定期点検等により運転停止，再運転の運転温度から常温また運転温度までの繰返 し熱負荷及び繰返し内圧変化がガスケット接触応力に与える影響が問題となっている．このような繰返し温度変 化や繰返し内圧変動下の圧力機器のノズル(9)及び配管 ${ }^{(10)}$ の強度に関する研究がいくつかなされているが, 管フラ ンジ締結体接触面からの漏えいおよび密封性能評価に関する研究はなされていないようである。しばしば運転停 止時及び再運転時に管フランジ締結体からの漏えい事故も発生している．しかし，その原因については不明のま まで, ボルト初期締付け力の設定にも明確な根拠は乏しく, 漏えい後, 経験的にボルトの増し締めなどを行うこ ともあるようである。

また，ボルト - ナットと管フランジの材質が等しい場合を想定し，締結体に温度変動が発生する場合の単純な ガスケットと管フランジの線膨張差のみによるボルト軸力変動及びガスケット接触応力変化の推定が検討されて いる. しかし実際の管フランジ締結体はボルトの初期締付け力の設計值, 配管施工の作業性及び使用環境の観点 からボルト - ナットの材質と管フランジの材質が異なる場合が発生するようである.これらフランジ材質の差異, 特に管フランジ，ボルト及びガスケットの線膨張係数の差異が温度変動下での締結体のガスケット接触応力の変 化及び密封性能に及ぼす影響に関する研究はあまりなされていない.このため締結体に温度変化や内圧が変化す る場合に科学的根拠がないままに締結体ボルトの増し締めが行われているのが現状のようである．多大な漏えい 事故を未然に防ぎガスケット付き管フランジ締結体をより長期的に安全に使用できる合理的設計法の確立のため には，これらの影響を検討する必要があると考えられる．しかしそのような研究はあまりなされていないのが現 状であり, 漏えい事故発生防止の対策が必要とされている.

世界的な管フランジ締結体設計は, 作動流体が気体の場合にはガスケット部分から必す微小漏えいが発生する という前提に立ち, 米国の圧力容器研究委員会 (PVRC) がタイトネスパラメータ $T_{p}$ 及び新ガスケット係数 $G_{b}, a$, $G_{s}$ を用いた密封性能の評価法と, ボルト初期締付け力の決定方法を提案している ${ }^{(11) \sim(14)}$. 近年, 国内でも, 気体の 漏えい量を用いて締結体の密封性能を評価する研究(15) (18)が行われている.

そこで, 本研究は従来その研究があまりなされていない実際の管フランジ締結体が運転，運転停止，再運転に より受ける繰返し温度変化及び内圧変化が管フランジ締結体の密封性能に及ぼす影響を明らかにし，さらにしば しば発生するプラントの再運転時のガスケットからの漏えい事故の原因にも言及し, より長期的に微小漏えいを 考慮した管フランジ締結体の合理的設計法確立のための基礎的資料を提供することを目的としている. まず，運 転, 運転停止, 及び再運転の一連サイクルを考慮した繰返し内圧変化及び温度変化作用下での，（1）締結体のガ スケット接触応力分布及びボルト軸力の変化を有限要素応力（FEM）解析により明らかにする. これらの結果に 基づき，（2）内圧作用及び温度変動下での漏えい量基準の管フランジ締結体のボルト初期締付け力の決定及びボ ルトの増し締め作業の必要性について検討する.（3）管フランジ締結体設計に重要な管フランジとボルト - ナッ 卜材質の選定が管フランジ締結体のガスケット接触灾力に与える影響についても検討し, 従来発生している運転 停止時及び再運転時での締結体からの漏えい事故に至る原因についても検討寸る.

他方で実際の管フランジ締結体を用いて同様の繰返し内圧変化及び温度変動下で漏えい量測定実験を行い，繰 返し内圧変化及び温度変化が管フランジ締結体の密封性能に及ぼす影響を明らかにする．また，実験により得ら れた結果と FEM 応力解析より推定される漏えい量の結果を比較し, FEM 応力解析による漏えい量推定の妥当性 を検討する. FEM 応力解析及び実験により一連のサイクルを厳密に検討した後, 実務上で必要となる使用限度を 検討するため複数回の繰返し温度変化が密封特性に及ぼす影響を 21 日間の漏えい量測定実験を行い明らかにす る.

\section{2. 有限要素応力解析}

図 1 は内圧 $P$ 及び温度変化が作用するガスケット付管フランジ締結体を示寸. 雾囲気温度 $T_{0}$ で 1 枚のガスケッ 卜を挟む 1 組の管フランジを目標ボルト初期締付け力 $F_{f}$ によって締付けた後, 締結体に内圧 $P$ が作用すると軸力 方向引張力 $W\left(=\pi a_{1}^{2} P\right)$ が管端に生じ, 各ボルト軸力が $F_{t}$ だけ増加し, このボルト 1 本付近のガスケット接触面 からは $F_{c}$ だけの圧縮力が失われる. さらに管フランジ締結体全体を一様に $T_{h}$ に温度を上昇させる. この時のガ スケット接触応力分布を求める. 
図 2 は有限要素法（FEM）解析モデルの一例を示す．管フランジ締結体の対称性を考慮し 8 分の 1 モデルを用 いてガスケット接触応力分布及びボルト軸力変化の解析を行う. FEM 解析コードは ANSYS であり, 要素数及び 節点数はそれぞれ 63000 及び 69667 としている. 解析モデルの寸法は, 漏えい量測定実験に使用する呼び径 2 イ ンチの管フランジ締結体 (JPI 規格 ${ }^{(19)}$ ) の寸法と同一寸法とする. 寸なわちフランジ外径が $165 \mathrm{~mm}$, 内径 $49.5 \mathrm{~mm}$,

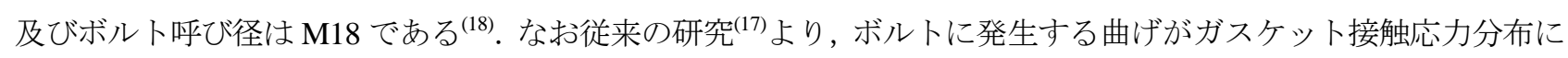
及ぼす影響は小さいと推測される。図 3 は FEM 応力解析に用いた測定されたガスケットの応力 - ひずみ線図を 示す，縦軸はガスケット応力を示し，横軸はガスケットの圧縮ひずみを示寸．ガスケット温度を $50^{\circ} \mathrm{C}$ から $300^{\circ} \mathrm{C}$ までとしている．用いたガスケットは膨張黒鉛うず巻形ガスケット（Spiral wound gasket:SWG）である. 一般的 によく知られているガスケットの非線形性と負荷曲線と除荷曲線の差異, いわゆるヒステリシスも考慮に入れて 解析を行う。

図 4 は膨張黒鉛 SWG の作用温度による線膨張ひずみを示す. 綐軸はガスケットの厚さ方向の伸びひずみ $\varepsilon$, 横 軸は加熱温度 $T$ を示す. 約 $210^{\circ} \mathrm{C}$ までの加熱 $T$ に対して温度とひずみ $\varepsilon$ はほぼ線形的に変化するが, $210^{\circ} \mathrm{Cを}$ 超え ると，この線図 $(T-\varepsilon)$ の傾きが変化する. この線図 $(T-\varepsilon)$ の傾きより SWG の線膨張係数が算出できる. その結 果この SWG の線膨張係数は $\lambda=218.1 \times 10^{-6} / \mathrm{K}$ ( $210^{\circ} \mathrm{C}$ 以下),$\lambda=29.0 \times 10^{-6} / \mathrm{K}\left(210^{\circ} \mathrm{C}\right.$ 以上) となる. ここで膨張黒鉛 単体の線膨張係数は $200 \times 10^{-6} / \mathrm{K}$, ステンレスの線膨張係数は $16.4 \times 10^{-6} / \mathrm{K}$ である. 膨張黒鉛 SWG の線膨張係数が 約 $210^{\circ} \mathrm{C}$ で変化する原因の一つとして, 膨張黒鉛 SWG がステンレス製の内輪、外輪, ピラー及び膨張黒鉛で構成 されているため, 約 $210^{\circ} \mathrm{C}$ を境にこれらの構成要素の相互作用により生じたと考えられる. 温度上昇時と温度下 降時では, ガスケットの厚さ方向の伸び測定にはわずかな差異があるもののかなり小さいため, 温度上昇時の測 定結果を用いて解析を行う。

図 5 は JIS B $2490^{(18)}$ より得られる本研究で用いる SWG の基本漏えい量（Leak rate）とガスケット応力 $\left(\sigma_{z}\right)$ の 関係を示す. 縦軸は基本漏えい量 $L_{S}\left(\mathrm{~Pa} \cdot \mathrm{m}^{3} / \mathrm{s}\right)$ を示し, 横軸はガスケット応力 $\sigma_{z}$ を示す. JIS B $2490^{(18)}$ の規定 に従い, ガスケットの負荷時及び除荷時の漏えい量の測定を行った. この場合は常温の結果である. $100^{\circ} \mathrm{C}, 200^{\circ} \mathrm{C}$ 及び $300^{\circ} \mathrm{C}$ の温度条件下で JIS B $2490^{(18)}$ に準じて漏えい量測定実験を行ったが同様の結果が得られた.

FEM 応力解析により, 各種機械構造物の配管接合部で使用される管フランジ締結体の運転, 運転停止, 及び再 運転により作用する繰返し温度変化及び内圧変化が管フランジ締結体の，1）ガスケット接触応力分布の変化及び ボルト軸力変動に及ぼす影響, 2) 管フランジとボルト材質の差異, 特に線膨張係数の差異がガスケット接触応力 分布の変化に及ぼす影響, も明らかにする.

図 6 は繰返し温度変化及び内圧変化のシーケンスを示す．縦軸は各温度 $T$ 及び内圧 $P$ を示す．横軸はステップ

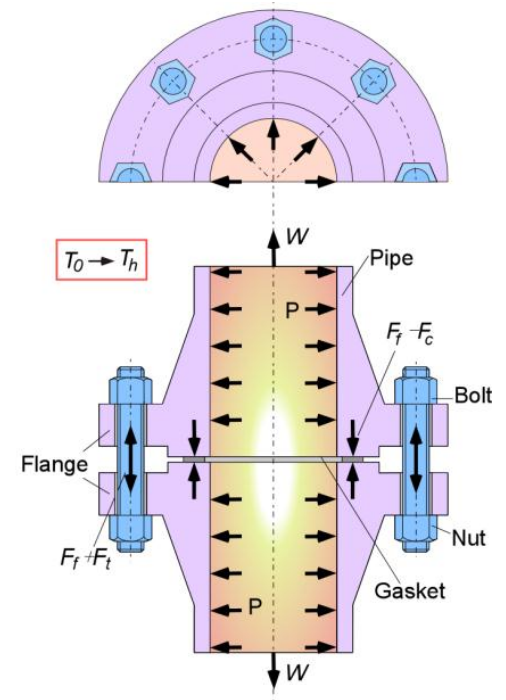

Fig.1 A pipe flange connection with spiral wound gasket subjected to internal pressure under elevated temperature

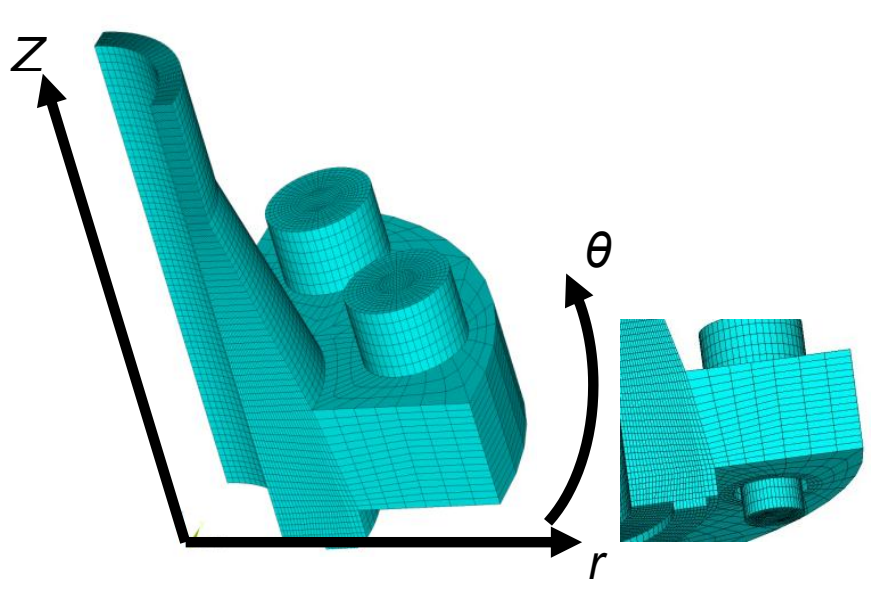

Fig.2 An example of mesh divisions used in FEM calculations 


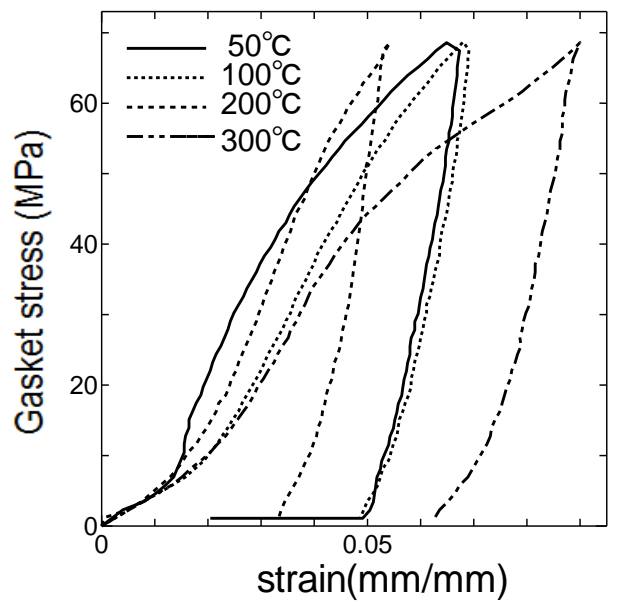

Fig.3 Measured stress-strain curves of the gasket (SWG) under elevated temperature

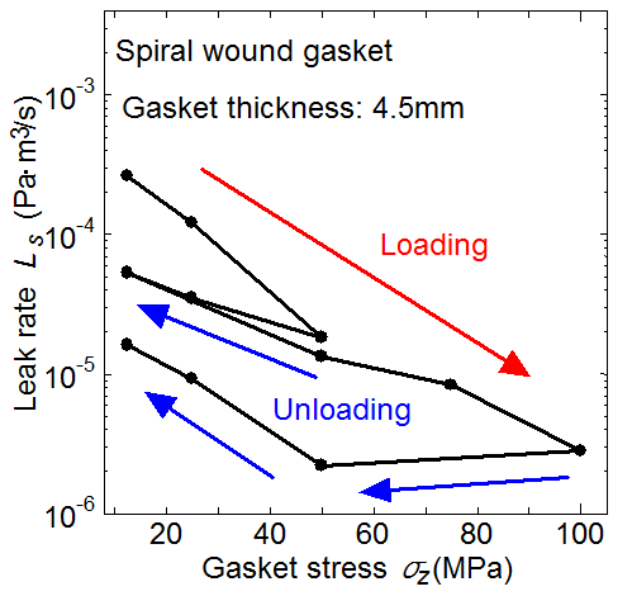

Fig.5 The measured relationship between gasket stress and leak rate for SWG according to JIS B $2490^{(16)}$

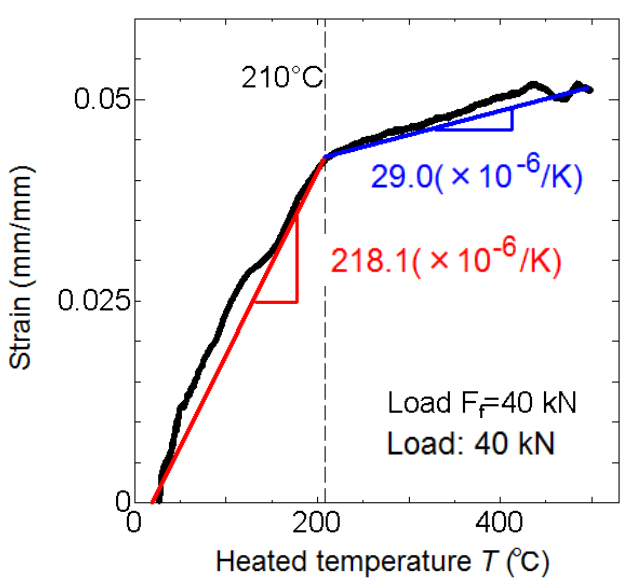

Fig.4 Thermal expansion of SWG as a function of temperature

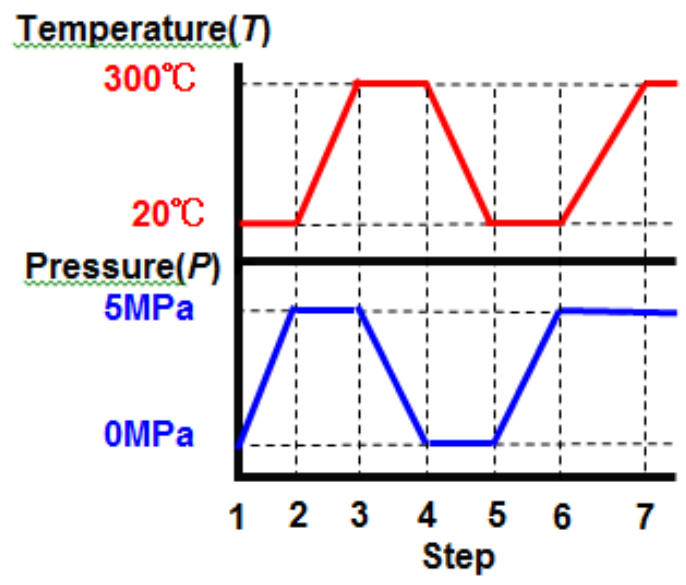

Fig.6 Test sequence for pipe flange connection under cyclic thermal condition and internal pressure

番号を示す．管フランジ締結体に作用する繰返し温度変化及び内圧変化は，まず管フランジ締結体のボルト初期 締付け（常温 $\left.T=20^{\circ} \mathrm{C}\right)$ をステップ 1 とし，その後，運転開始とし内圧 $(P=5 \mathrm{MPa})$ を作用させ (ステップ 2$)$, 運 転中とし内圧 $(P=5 \mathrm{MPa})$ を保持し, 温度変動（ $T=20^{\circ} \mathrm{C}$ から $T=300^{\circ} \mathrm{C}$ 一 $)$ を締結体に与える（ステップ 3$)$ ，その 後, 定期点検等による運転停止によりまず内圧を $P=0 \mathrm{MPa}$ とし (ステップ 4$)$, その後温度を常温 $\left(T=20^{\circ} \mathrm{C}\right)$ とす る (ステップ 5$)$ ，点検後，再運転が開始され内圧が負荷される（ステップ 6)，その後温度 $T$ が上昇する $\left(T=20^{\circ} \mathrm{C}\right.$ から $T=300^{\circ} \mathrm{C}$, ステップ 7).

またボルト - ナット及び管フランジ材質の差異（線膨張係数の差異）が，ガスケット接触応力分布に及ぼす影 響を検討する．表 1 はボルト - ナットと管フランジ材質の組み合わせを示す．管フランジ締結体のフランジ材料 は数多くの種類があり,この線膨張係数はボルト及びガスケットの線膨張係数と異なる。このため三つの場合 (表 1) すなわち, フランジ及びボルトの線膨張係数が等しい場合, フランジの線澎張係数がボルトのそれより小さ い場合およびフランジの線膨張係数がボルトのそれより大きい場合に対して温度変動下での締結体の特性を調べ る必要がある. ボルト - ナット及び管フランジが同種 (SUS304) の場合 (case 1), 異種 (ボルト - ナット: SUS304, 管フランジ：S45C（case 2）及びボルト - ナット:S45C，管フランジ:SUS304（case 3)）に対して締結体のガスケ ット接触応力分布及びボルト軸力変化の解析を行う. 線膨張係数には温度依存性があるが $25^{\circ} \mathrm{C}$ 代表值として比 
Table 1 Material combinations for the pipe flange and bolt-nut materials

\begin{tabular}{|c|c|c|c|}
\hline & Case1 & Case2 & Case3 \\
\hline Pipe & Stainless & Stainless & Carbon \\
flange & steel & steel & steel \\
\hline $\begin{array}{c}\text { Bolts } \\
\text { and nuts }\end{array}$ & $\begin{array}{c}\text { Stainless } \\
\text { steel }\end{array}$ & $\begin{array}{c}\text { Carbon } \\
\text { steel }\end{array}$ & $\begin{array}{c}\text { Stainless } \\
\text { steel }\end{array}$ \\
\hline
\end{tabular}

較すると，それぞれの線膨張係数は，ステンレス鋼（SUS304）は $16.4 \times 10^{-6} / \mathrm{K}$ であり，炭素鋼（S45C）は 10.9×10 /K である(20). したがって，ステンレス鋼の方がその值が大きい。 なお FEM 応力解析においてはステンレス鋼及 び炭素鋼の線膨張係数と縦弹性係数は温度依存性を考慮している(20).

\section{3. 有限要素応力解析結果}

図 7 は FEM 応力解析により得られた繰返し内圧変化及び温度変動を受ける管フランジ締結体の各ステップに おけるガスケット接触応力分布の変化を示す. 縦軸はガスケット接触応力 $\sigma_{z}$, 横軸はフランジ中心からの距離 $r$ をガスケット内半径 $a_{3}$ で無次元化した值を示す. ボルト初期締付けカ $F_{f}$ は, ボルト締付け時の平均ガスケット接 触応力 $\sigma_{z m}$ がまず $100 \mathrm{MPa}$ となるように決める． $\sigma_{z m}=100 \mathrm{MPa}$ は実際に使用される值としてはかなり大きい．ボル ト -ナット及び管フランジの材質はともにステンレス鋼（SUS304）である（表 1 ：case 1). 図 7 より，ボルト初 期締付け（ステップ 1）によりガスケット接触応力は約 100MPa を示し（図 7 中、番号 1), 運転開始時（ステッ プ 2) には内圧作用によりガスケット接触応力は減少し（図 7 中, 番号 2), 運転時 (ステップ 3) では温度変動 によりガスケット接触応力がかなり大きく上昇する (図 7 中, 番号 3). 運転停止に伴い内圧が除荷 (ステップ 4) されガスケット接触応力はわずかに増加し（図 7 中, 番号 4), 温度変動 $\left(300^{\circ} \mathrm{C}\right.$ から $20^{\circ} \mathrm{C}$ : ステップ 5) により ガスケット接触応力は大きく減少する（図 7 中, 番号 5)。その後再運転開始時（ステップ 6) にガスケット接触 応力がさらに減少し, 最も小さくなる（図７中, 番号 6). 再運転時（ステップ7）にはガスケット接触応力は上 昇寸るが運転時のガスケット接触応力より小さな值となることが分かる（図 7 中, 番号 7). 以後ステップ 1 をボ ルト初期締付け時，ステップ 2 を運転開始時，ステップ 3 を運転時，ステップ 4 を運転停止時，ステップ 5 を点 検時, ステップ 6 を再運転開始時, 及びステップ 7 を再運転時とする. 本解析により点検後の再運転開始時にガ スケット接触応力が平均約 $\sigma_{z}=40 \mathrm{MPa}$ となり, 最も小さくなることが明らかにされている. 実際の現場でのフラ ンジ締結体の漏えい事故は再運転時に しばしば発生していることと対応すると考えられる.長期に各種機械構造 物を安全に運転し続けるためにはこの再運転開始時の減少したガスケット接触応力を考慮してボルト初期締付け 力を決定する必要がある.

図 8 はボルト - ナット及び管フランジ材質が異種の場合のガスケット接触応力分布(内圧作用下のみ)を示す. 図 8(a) は表 1 中の case 2 の場合の結果を示し, 図 8(b)は同 case 3 の場合の結果を示す.この一連のシーケンス内 で実際に漏えいと関係するのは管フランジ締結体に内圧が作用する時のみのため, ガスケット接触応力の表示は ステップ 2, ステップ 3, ステップ 6 及びステップ 7 のみとする. 表 1 中の case 2 及び case 3 の組み合わせの管フ ランジ締結体でも, case1 同様に内圧変化及び温度変動によるガスケット接触応力分布の変化は, 変化の度合いに 関する大小はあるものの挙動は同一である.また再運転開始時に最もガスケット接触応力が減少することが示さ れている．再運転開始時のガスケット接触応力分布を case 2 及び case 3 の場合に対して比較すると， case 2 の場 合がより小さくなり，ガスケット接触灾力は約 $20 \mathrm{MPa}$ である. case 2 の組み合わせは管フランジがステンレス鋼 でありボルト - ナットが炭素鋼である. 炭素鋼の線膨張係数はステンレス鋼のそれより小さいため, 締結体に温 度変動が発生した時ボルト - ナットが管フランジより熱膨張量が小さい. したがって, 他のケースに比べ管フラ ンジ締結体として最も大きな圧縮熱ひずみが発生している.このため, 温度変動時のガスケット接触応力は case 2 
の場合がもっと大きい (ステップ 3). しかし, 温度が低下寸ると, 発生した大きな熱ひずみ分だけ除荷される. さらに, ガスケットはヒステリシスの特性を有するため, 図 3 に示す負荷曲線の傾きと除荷曲線の傾きでは除荷 曲線の傾きが極めて大きい. これらの影響により case 2 の場合の締結体に対して再運転開始時のガスケット接触 応力が最も小さくなると考えられる．この減少した最小のガスケット接触応力が漏えいに対して十分かを吟味す る必要がある. 図 5 の結果を参照することにより， $\sigma_{z}=20 \mathrm{MPa}$ であると，先に述べた $\sigma_{z}=40 \mathrm{MPa}$ の場合に比べて締 結体の漏えい量がやや増大寸ることが推測される.

図 9 は管フランジ及びボルトの材質を表 1 中の case 2 とし, ボルト初期締付け時の平均ガスケット接触応力 $\sigma_{z m}$ を70MPa とした場合のガスケット接触応力変動を示す。ここでボルト初期締付け時の平均ガスケット接触応力 $\sigma_{z m}=70 \mathrm{MPa}$ は，一般的な SWG の最小設計締付け圧力 ${ }^{(21)(22)}\left(\sigma_{z m}=68.9 \mathrm{MPa}\right)$ と同等の值である.この結果より, 再 運転開始時（図 8 中，番号 6）のガスケット接触応力がほぼ 0MPa となることが示されている．これは，必ず多 大な漏えいが生じることを示し, 現実に発生するプラントの再運転時の漏えい事故に対応寸るものと推測される. したがって, 運転停止時にボルトの増し締め作業を行うか, 又は, 図 8(a)に示すように予めボルト初期締付け力 をより大きくすることを検討する必要がある，すなわち，本論文で示している一連のシーケンスによるガスケッ 卜接触応力の減少を考慮し，合理的ボルト初期締付け力の設定を行う必要がある.

図 10 は繰返し内圧及び温度変化が作用する管フランジ締結体の各ステップにおける平均ガスケット接触応力

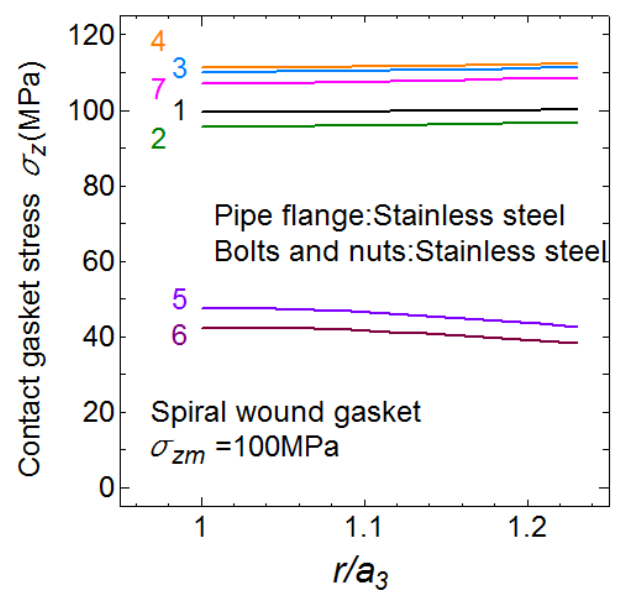

Fig.7 Changes in contact gasket stress distributions in pipe flange connection (case 1 in table 1 , case of the same material, $\sigma_{z m}=100 \mathrm{MPa}$ ))

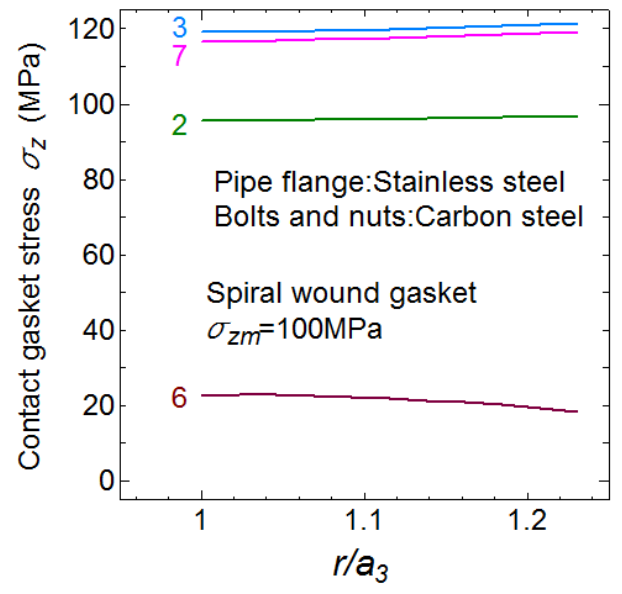

Fig.8(a) Changes in contact gasket stress distributions in pipe flange connection (case 2 in Table 1)

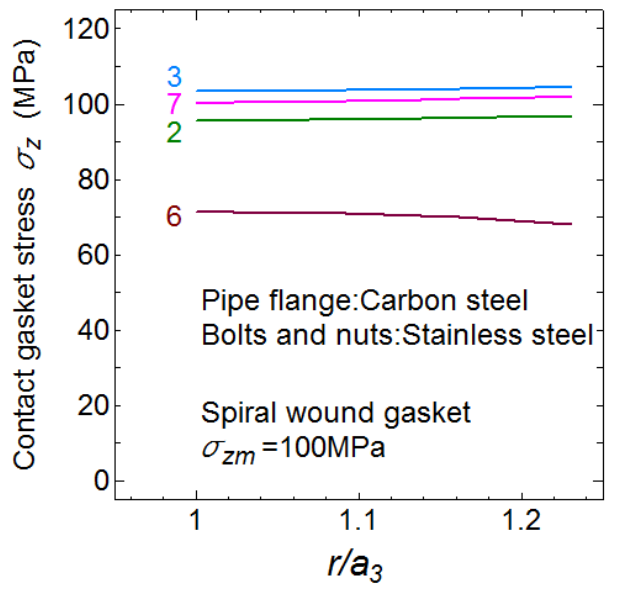

Fig.8(b) Changes contact gasket stress distributions in pipe flange connection (case 3 in Table 1) 


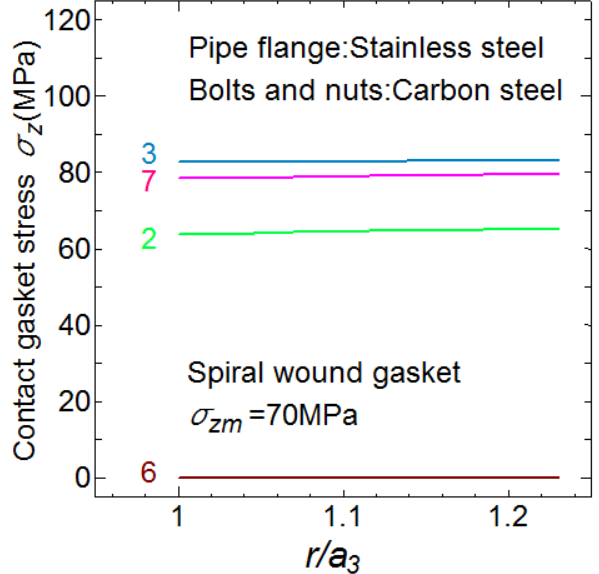

Fig.9 Changes in contact gasket stress distributions in pipe flange connection (case $2: \sigma_{z m}=70 \mathrm{MPa}$ )

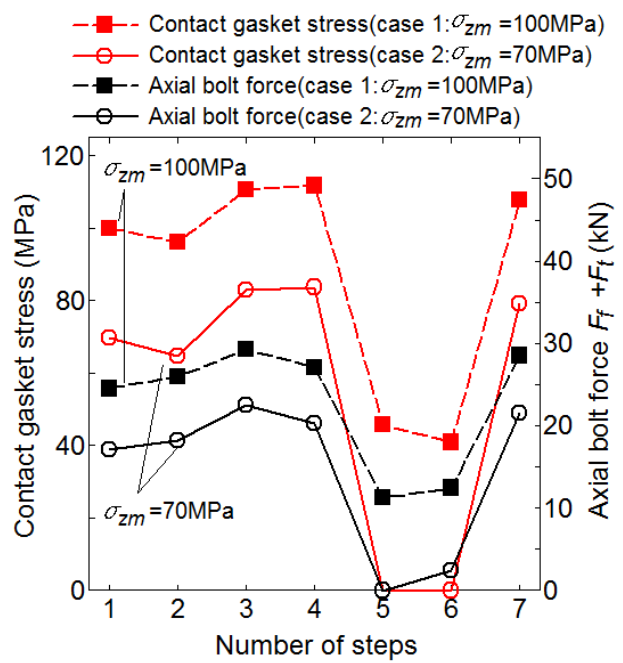

Fig.10 Axial bolt force changes in each step (case 1:100MPa \&case 2:70MPa)

及びボルト軸力変動を示す．初期平均ガスケット接触応力は 100MPa（表 1 中 case1，図中の匚）及び 70MPa（表 1 中 case2, 図中の○) である. 縦軸は平均ガスケット接触応力及びボルト軸力 $\left(F_{f}+F_{t}\right)$ を示し, 横軸はステップ 番号を示寸．この図より，ボルト軸力の変化とガスケット接触応力の変化は同様の傾向がみられ，運転時（ステ ップ 3）と再運転時（ステップ 7）ではボルト軸力の差はかなり小さい. したがって，ボルト初期締付け力が十分 に大きい場合（ $\sigma_{z m}=100 \mathrm{MPa}$ 表 1 中 case1），再運転開始時のガスケット接触応力（約 $40 \mathrm{MPa} ）$ はかなり減少する が漏えい量は $1 \times 10^{-6}(\mathrm{~Pa} \cdot \mathrm{m} 3 / \mathrm{s})$ から $1 \times 10^{-5}(\mathrm{~Pa} \cdot \mathrm{m} 3 / \mathrm{s})$ オーダ（図 5）の範囲内である. このため漏えい防止の ために, あえてボルトの増し締め作業を行う必要ないと考えられる. しかしガスケット接触态力がかなり減少す ることの認識は必要である. 他方で，ボルト初期締付け力が SWG を用いるときの常識的な值 $\left(\sigma_{z m}=70 \mathrm{MPa}:\right.$ 表 1 中 case2）とすると, 再運転開始時のガスケット接触応力が $0 \mathrm{MPa}$ 及びボルト軸力もほぼ $0 \mathrm{kN}$ となる.このため 締結体から漏えいさせないためにはボルトの増し締め作業が必要となる．以上の結果より，管フランジ締結体か らの漏えい事故を防ぐためには，運転時に作用する内圧を対象にガスケット接触灾力を検討するのみならず，停 止時, 特に温度が低下した状態での残留ガスケット接触応力の維持についても考慮して, ボルトの初期締付け力 を検討する必要がある。

\section{4. 漏えい量測定実験}

実際のガスケット付き管フランジ締結体を用いて繰返し温度変化及び内圧作用をさせた時の管フランジ締結体 からの漏えい量を測定する. 図 11 は実験装置の概要を示寸．FEM 応力解析と同様のシーケンスで管フランジ締 結体に繰返し温度変化及び内圧変化を作用させる．温度変動はカートリッジヒータにより作用させ締結体に設置 した熱電対により温度を制御する．また管フランジ締結体は一様な温度状態となるように締結体全体を断熱材で 覆っている. 常温 $\left(20^{\circ} \mathrm{C}\right)$ から $300^{\circ} \mathrm{C}$ まで 12 時間かけてゆっくり昇温し定常状態となることを確認している. $300^{\circ} \mathrm{C}$ から常温 $\left(20^{\circ} \mathrm{C}\right)$ の降下も同様に 12 時間としている. 作動流体はへリウムガスを使用し, ひずみゲージ式圧力変 換器により内圧を測定する. 各ボルトのボルト初期締付け力は, ボルト締付け時の平均ガスケット接触応力が 100 $\mathrm{MPa}$ となるように決定し，ボルト軸部に貼った 2 枚の校正済みひずみゲージよりボルト軸力相当のひずみデータ を出力させ正確にボルト初期締付けを行う。管フランジ締結体からの漏えい量は圧力降下法(15)を用いて測定する.

管フランジの呼び径及び呼び圧力は 2inch，JPI Class600 である. FEM 応力解析では管フランジ，ボルト - ナッ ト材質を変化させた FEM 応力解析も行ったが，管フランジ及びボルト-ナットの材質は SUS304 の同種のみの締 結体に対して実験を行う（表 1 中の case 1)。使用したガスケットは膨張黒鈆 SWG である.

また複数回の繰返し温度変化が密封性能に及ぼす影響を明らかにするために, 繰返し温度変化を与え, 漏えい 


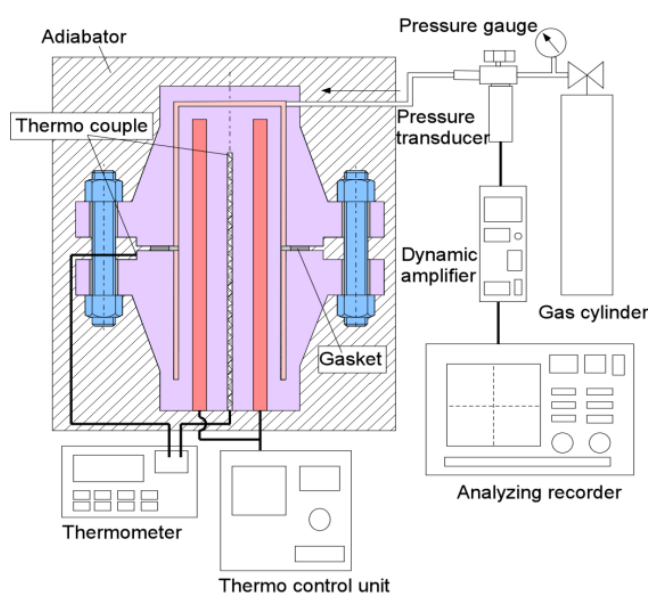

Fig.11 Schematic of experimental setup for pipe flange connection under cyclic thermal change condition and cyclic internal pressure

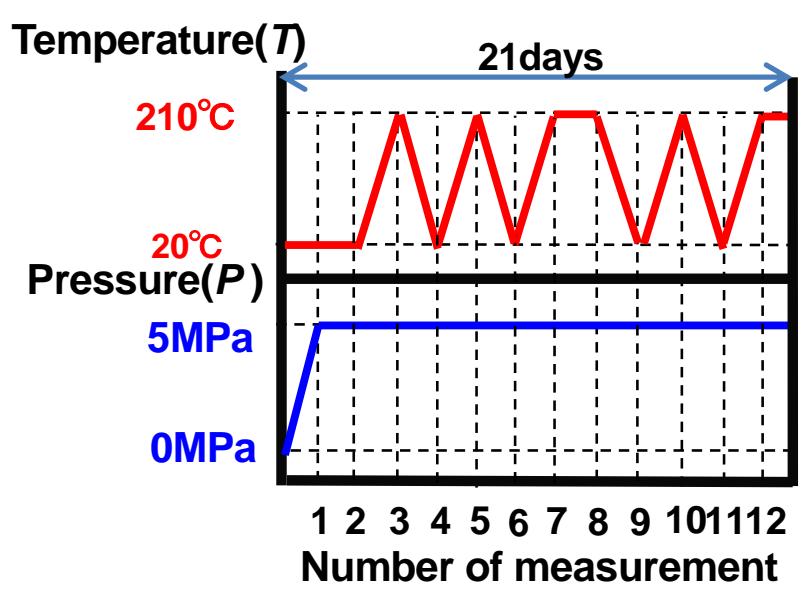

Fig.12 Test sequence for gasket leakage test under cyclic thermal change condition

量測定実験を行う。図 12 は作用させたシーケンスを示す。縦軸は測定時の各温度 $T$ 及び内圧 $P$ を示す．横軸は 漏えい量の測定回数を示す. 期間は 21 日間とした. 本実験では一定の内圧作用下において締結体に温度変動を与 え，ある温度条件における締結体の漏えい量測定が終了寸ると次の温度条件に移行し締結体の漏えい量を測定す る. 21 日の間このインターバルで締結体の漏えい量測定を行っている. ここでは密封特性を PVRC が提案する タイトネスパラメータ ${ }^{(9))(12)}$ で評価する. タイトネスパラメータは $T_{P}=P / P^{*}\left(L_{r m}^{*} / L_{r m}\right)^{0.5}$ で計算されれ)(12), その 数值が大きいほど密封性能が良いことを示す。ここで $P$ は内圧, $P *$ *大気圧, $L_{r m}$ は質量漏えい量, $L_{r m *}$ は参照質 量漏えい量である.

\section{5. 漏えい量測定実験結果}

図 13 は実際の管フランジ締結体を用いて行った漏えい量測定実験の結果を示す.管フランジ締結体に与えた繰 返し内圧変化及び温度変化は FEM 計算と同一とした．縦軸は漏えい量 $\left(\mathrm{Pa} \cdot \mathrm{m}^{3} / \mathrm{s}\right)$ を示し, 横軸はステップ番号 を示す．漏えい量測定は管フランジ締結体に内圧が作用する場合のみとなるため, ステップ 2, ステップ 3 , ステ ップ 6 及びステップ 7 のみとする. FEM 応力解析より得られたガスケット接触応力分布から平均ガスケット接触 応力を求め, 計算された平均ガスケット応力の值を, JIS B $2490^{(16)}$ より得られるガスケットの基本漏えい量測定結 果（図 5）に適用することにより，管フランジ締結体からの漏えい量を推定する ${ }^{(8)(15)}$. 図中の赤色の破線は推定 結果を示寸.この図より, 運転時（ステップ 3）及び再運転時（ステップ 6) の密封性能と比較し運転停止時及び 再運転開始時の締結体の漏えい量がより多く, 密封性能がより低いことが示されている. また, 運転時及び再運 転時の締結体の密封性能の差異は小さく, 適切なボルト初期締付け力で締結された管フランジ締結体では繰返し 温度変化及び内圧変化が締結体の密封性能に及ぼす影響は小さい。この結果は FEM 応力解析によって得られる 図 7 に示されるガスケット接触応力の変化と対応している. 漏えい量に関寸る実験結果と推定結果の比較では, 推定結果の方が大きな值をしている. この原因として次のことが挙げられる. 1) ガスケット接触応力の平均值を 使用するためガスケット接触応力の最大值が無視される，2）ガスケットの「馴染夕」等. しかし，実験結果と推 定された漏えい量はオーダ的にはかなりよく一致しており, FEM 応力解析を用いての締結体の漏えい量推定結果 は妥当であると言える.

図 14 は管フランジ締結体での 21 日間の漏えい量測定実験（図 12）の結果を示す. 実務上の観点からガスケッ 卜交換の時期を決定する必要がある. そのために複数回の繰返し温度変動が締結体の密封性能に及ぼす影響を明 らかにすることが重要とされている. 縦軸はタイトネスパラメータ ${ }^{(9)}(12)$ 及び作用温度を示し, 横軸には経過日数 を示寸，ひし形（け）は締結体の密封性能（タイトネスパラメータ）を示し，四角（口）は作用温度を示寸. 繰 


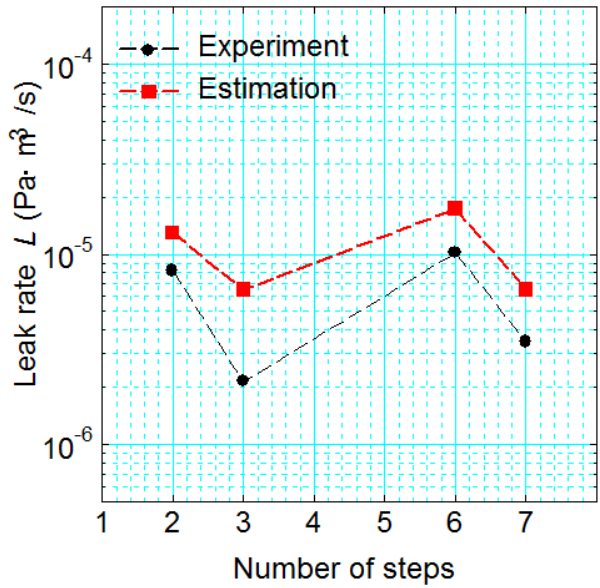

Fig.13 The comparison between leak rate obtained from leakage test using the actual pipe flange connection and that obtained from FEM results (2" flange)

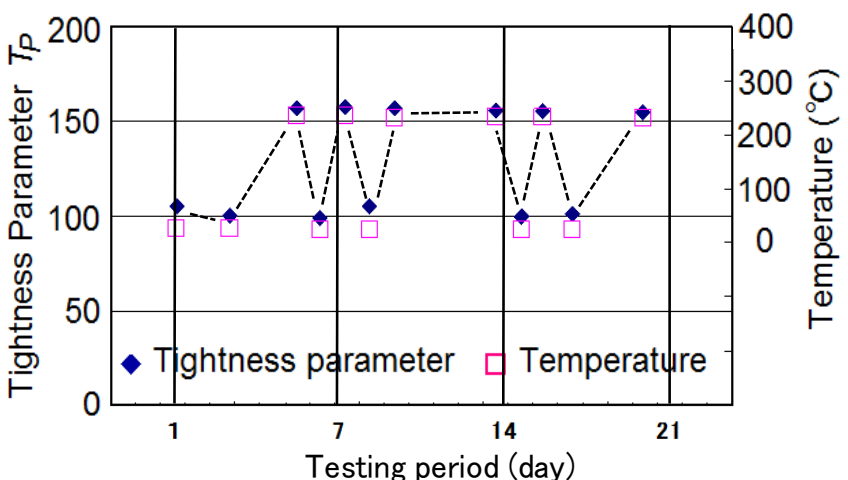

Fig.14The results of the sealing performance of the connection under 4 repeated times for 21 days

返し温度変動を 21 日間かけて 4 回作用させた結果, 締結体が温度上昇した場合, 締結体の密封性能は向上し, 温 度を除荷しても初期締付け時の密封性能を示している. 4 回の温度変化が与えられても管フランジ締結体の密封 性能の変化は小さい. 十分なボルト初期締付け力を付与した結果, 繰返し数が 4 回の漏えい量測定実験 (21 日間) からはガスケット自体の劣化等は発生しないと推測され，密封性能は一定であるという結果が得られている．実 務における第一種圧力容器の一般的なガスケット使用期間（2 年）を考慮してこの繰返し数 4 回は十分に実務に 対応できると考えられる.

\section{6. 結言}

繰返し温度変動及び内圧変化がガスケット付き管フランジ締結体の力学特性及び密封性能に及ぼす影響につい て有限要素応力解析及び実際の管フランジ締結体を用いた漏えい量測定実験を行い，解析及び実験の両面からそ の影響を明らかにした。得られた結果は以下の通りである.

1. 有限要素応力解析により, 実際のプラントの運転, 停止, 再運転に対応する繰返し内圧変化及び温度変動 下での管フランジ締結体のガスケット接触応力分布の変化を明らかにした．この結果より，再運転開始時 のガスケット接触応力が最も小さな值となることが分かった．したがって，この時のガスケット接触応力 が許容漏えい量を満足するようにボルトの初期締付け力を決定する必要があることを示した.

2. ボルト - ナット材質及び管フランジ材質の差異により, ガスケット接触応力分布の変化量が異なることを 示し，温度上昇時に大きな熱ひずみを発生する材料選定では温度が降下した時に，ガスケット接触応力が 大きく減少することが分かった．これはしばしば発生する現場での事故と対応する．特にうず巻形ガスケ ットを用いたときに, 初期平均ガスケット接触応力を $100 \mathrm{MPa}$ とすると, ガスケット接触応力が減少する が，最小で 20MPa となり，この場合には漏えい量は僅かに増大寸るが十分な密封性能を有することを示 した. しかし通常施工時に締付けられる平均ガスケット接触応力 $\sigma_{z m}=70 \mathrm{MPa}$ ではガスケット接触応力及び ボルト軸力もほぼゼロとなり, 漏えい事故につながることを指摘し, 適切なボルト初期締付け力の設定の 重要性を指摘した。

3. 繰返し温度変化及び内圧変化作用下でのボルト軸力変化を明らかにした. ボルト軸力はガスケット接触応 力と同様の変化を示し, 運転時と再運転時ではほぼ同じボルト軸力の值を示した. この結果から, 再運転 時に許容漏えい量範囲内であればボルトの増し締め作業は必要ないことが示された. しかし，最もガスケ ット接触応力が小さくなる時に漏えいに対して十分かどうかのチェックが必要なことが分かった. 
4. 実際の管フランジ締結体を用いて漏えい量測定実験を行った. その結果，適切なボルト初期締付け力で締 結された管フランジ締結体では繰返し温度変化及び内圧変化が漏えいに及ぼす影響は小さいことが分か った. FEM 応力解析によって得られたガスケット接触応力分布を用いての漏えい量推定結果と測定結果 はかなりよく一致することを示した。また，実務上有用である 4 回の繰返し数での漏えい量測定実験（21 日間）でも繰返し温度変化の影響が密封性能に及ぼす影響が小さいことが示された.

\section{文献}

(1) Kumano, H., Sawa, T., and Hirose, T., "Mechanical Behavior of Bolted Joints under Steady Heat Conduction", Transactions of the ASME, Journal of Pressure Vessel Technology, Vol.116, Issue1 (1994), pp.42-48.

(2) Sawa, T., Takagi, Y., and Yamada, K., "Evaluation of the sealing performance in bolted flange connection under heat condition and internal pressure (the effect of scatter in bolt preloads)", Proceedings of ASME, PVP2006-ICPVT-11, (2006).

(3) Abid, M., "Determination of safe operating conditions for gasketed flange joint under combined internal pressure and temperature: A finite element approach", International Journal of Pressure Vessels and Piping, Vol. 83, Issue 6 (2006), pp.433-441.

(4) Nechache, A., and Bouzid, A.H., "Creep analysis of bolted flange joints", International Journal of Pressure Vessels and Piping, Vol.84, Issue 3 (2007), pp.185-194.

(5) Sawa, T., Takagi, Y. and Torii, H., "Sealing Performance Evaluation of Pipe Flange Connection Under Elevated Temperatures", Proceedings of ASME PVP2007/Creep 8 Conference, (2007).

(6) Abid, M., Chattha, J.A., and Khan, K.A., "Finite Element Analysis of a Gasketed Flange Joint Under Combined Internal Pressure and Thermal Transient Loading", Proceedings of ASME PVP2007/Creep 8 Conference, (2007).

(7) Takagi, Y., Torii, H., Sawa, T. and Kawasaki, N., "Stress Analysis Sealing Performance Evaluation of Pipe Flange Connection At Elevated Temperature", Proceedings of ASME PVP2008 Conference, (2008).

(8) Omiya, Y., and Sawa, T., "Thermal Stress Analysis and the Sealing Performance Evaluation of Bolted Flange Connection at Elevated Temperature “, Proceedings of ASME PVP2009, (2009).

(9) Lang, H., Rudolph, J., Ziegler, R., "Performance Study of Ke Factors in Simplified Elastic Fatigue Analyses with Emphasis on thermal cyclic loading", International Journal of Pressure Vessels and Piping, Vol.88, Issue.8-9, (2011), pp.330-347.

(10) Farragher, T.P., Scully, S., O’Dowd, N.P., Leen, S.B., “Thermomechanical Analysis of a Pressurized Piping Under Plant Conditions" Journal of Pressure Vessel Technology, Vol.135, Issue.1, (2013), pp.1-9.

(11) Payne, J.R., Bazergui, A., and Leon, G.F., “A New Look at Gasket Factors”, Proceedings of 10th International Conference on Fluid Sealing, BHRA, H1 (1984), pp.345-363.

(12) Payne, J.R., Bazergui, A. and Leon, G.F., "New Gasket Factors-A Proposed Procedure," Proceedings of ASME PVP 1985 Conference, Vol.98, No.2 (1985), pp.85-93.

(13) Payne, J.R., Leon, G.F. and Bazergui, A., “Obtaining New Gasket Design Constants from Gasket Tightness Data," Proceedings of The 1987 Spring Conference on Experimental Mechanics, SEM, (1987), pp.298.

(14) Leon, G.F. and Payne, J.R., “An Overview of the PVRC Research Program on Bolted Flanged Connections," Proceedings of 6th International Conference on Pressure Vessel Technology, (1989), pp.217.

(15) Morohoshi, T., and Sawa, T., "On the Characteristics of Rectangular Bolted Flanged Connections with Gaskets Subjected to External Tensile Loads and Bending Moments", Transactions of the ASME, Journal of Pressure Vessel Technology, Vol.116, Issue 2 (1994), pp.207-215.

(16) Sawa, T., Nagata, S., and Tsuji, H., "New Development in Studies on the Characteristics of Bolted Pipe Flange Connections in JPVRC," Transactions of the ASME, Journal of Pressure Vessel Technology, Vol.128, Issue 1 (2006), pp.103-108.

(17) 高木愛夫, 大宮祐也, 小林隆志, 沢俊行, “フランジ呼び径が内圧を受ける管フランジ締結体の力学特性および密 封性能に及ぼす影響”, 圧力技術, Vol.50, No.3 (2012), pp.2-10.

(18) JIS B 2490, 管フランジ用ガスケットの密封特性試験方法, (2008), 日本規格協会.

(19) JPI-7S-15, 石油工業用フランジ, (2005), 石油学会. 
（20）理科年表，平成 21 年版 (2009), pp.413-41, 自然科学研究機構.

(21) バルカーハンドブック，(1997), 日本バルカー工業株式会社.

(22) ニチアス ハンドブック, (2007), p.56, ニチアス株式会社. 